Jpn. J. Pharm. Health Care Sci.
ノー

\title{
薬学実務家教員の実態に関する調査研究
}

\author{
矢野育子 ${ }^{* 2}$, 井関 健 $^{3}$, 東海林 徹 $^{4}$, 青山隆夫 ${ }^{5}$, 木津純子 ${ }^{6}$, 中村 均 $^{7}$, 藤井俊志 ${ }^{8}$, \\ 渡邊美智留 ${ }^{9}$, 野田幸裕 ${ }^{10}$, 脇屋義文 ${ }^{11}$, 森田邦彦 ${ }^{12}$, 手嶋大輔 ${ }^{13}$, 二神幸次郎 ${ }^{14}$ \\ 京都大学大学院薬学研究科 ${ }^{2}$, 北海道大学大学院薬学研究科 ${ }^{3}$, 奥羽大学薬学部 ${ }^{4}$, \\ 東京理科大学薬学部 ${ }^{5}$, 慶應義塾大学薬学部 ${ }^{6}$, 日本大学薬学部 7, \\ 高崎健康福祉大学薬学部 ${ }^{8}$, 武蔵野大学薬学部 ${ }^{9}$, 名城大学薬学部 ${ }^{10}$, \\ 北陸大学薬学部 ${ }^{11}$, 同志社女子大学薬学部 ${ }^{12}$, 就実大学薬学部 ${ }^{13}$, 福岡大学薬学部 ${ }^{14}$
}

\section{Survey on Situation of Pharmacist Faculties in Japanese Pharmacy Schools}

\author{
Ikuko Yano*2, Ken Iseki ${ }^{3}$, Tohru Shoji ${ }^{4}$, Takao Aoyama ${ }^{5}$, Junko Kizu ${ }^{6}$, Hitoshi Nakamura \\ Toshiyuki Fujii ${ }^{8}$, Michiru Watanabe ${ }^{9}$, Yukihiro Noda ${ }^{10}$, Yoshifumi Wakiya ${ }^{11}$, \\ Kunihiko Morita ${ }^{12}$, Daisuke Teshima ${ }^{13}$ and Koujiro Futagami ${ }^{14}$ \\ Graduate School of Pharmaceutical Sciences, Kyoto University ${ }^{2}$, \\ Faculty of Pharmaceutical Sciences, Hokkaido University ${ }^{3}$, School of Pharmaceutical Sciences Ohu University, \\ Faculty of Pharmaceutical Sciences, Tokyo University of Science, \\ Faculty of Pharmacy, Keio University, ${ }^{6}$ College of Pharmacy, Nihon University, \\ Faculty of Pharmacy, Takasaki University of Health and Welfare ${ }^{8}$, Faculty of Pharmacy, Musashino University ${ }^{9}$, \\ Faculty of Pharmacy, Meijo University ${ }^{10}$, Faculty of Pharmaceutical Sciences, Hokuriku University ${ }^{11}$, \\ Faculty of Pharmaceutical Sciences, Doshisha Women's College of Liberal Arts ${ }^{12}$, \\ School of Pharmacy, Shujitsu University ${ }^{13}$, Faculty of Pharmaceutical Sciences, Fukuoka University ${ }^{14}$
}

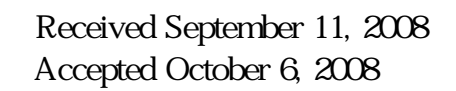

With the introduction of 6-year pharmacy educational program in 2006, a provision was made to assign pharmacist faculties having working experience as pharmacists in pharmacy schools. In October 2007, we conducted a survey to investigate the situation of pharmacist faculties.

We sent a questionnaire to 247 pharmacist faculties in 66 pharmacy schools and the response rate was $84.9 \%$. The faculties consisted of professors (43\%), associate professors (23\%) and lecturers (23\%), and $77 \%$ of them had a Ph.D. degree. In a typical week, the major activities they engaged in were educational activities (20.6 hrs), research (12.2 hrs) and management $(9.6 \mathrm{hrs})$. While the average time they were occupied by clinical practice was $3.5 \mathrm{hrs}, 67 \%$ of them did not do any. Half of the faculties did not conduct any research with students or graduate students in their own schools, and in 2007 only 55\% applied for Grant-in-aid for Scientific Research from the Ministry of Education, Culture, Sports, Science and Technology of Japan. Twenty-six percent said they were very satisfied or satisfied with their work on a five-point scale, and $44 \%$ rated their degree of satisfaction as fair.

In conclusion, our survey showed that most pharmacy faculties are not sufficiently engaged in clinical practice and do not spend much time in clinical research. We hope that its results will promote discussions among pharmacy personnel concerning the role of pharmacist faculties so that even better clinical pharmacy education may be provided to students in pharmacy schools.

Key words — pharmacist faculty, 6-year pharmacy education, clinical pharmacy, research

\section{緒言}

近年の医療技術の高度化，医薬分業の進展等に対応 し，医療人として資質の高い薬剂師の養成が必要との社
会ニーズを受け, 平成 16 年に学校教育法と薬剤師法が 改正され，平成 18 年度から薬学 6 年制教育課程が始まっ た1). 6 年制の教育課程では, 薬系大学を卒業した学生 が薬剂師としての一定の知識・技術・態度を修得できる ように, 薬学教育モデル・コアカリキュラムと実務実習

1 本研究は, 薬学実務家教員連絡会(仮称)の活動の一環として行った .

京都市左京区吉田下阿達町 46-29; 46-29, Shimoadachi-cho, Y oshida, Sakyo-ku, Kyoto-shi, Kyoto, 606-8501 Japan 
モデル・コアカリキュラムか導入され 病院および薬局に おける各々 11 週間の長期実務実習が規定されている2,3).

このように薬学 6 年制教育では臨床薬学教育の充実に 重点が置かれていることから，同時改正となった大学設 置基準では薬学 6 年制にかかる専任教員数の $1 / 6$ はおお むね 5 年以上の薬斉師としての経験を有する者(実務家) を含むという規定が新たに策定されだ綵。これに伴い， 全国の病院や保険薬局て指導的立場にあった多くの薬斉 師が実務家教員として大学に移籍した . 臨床薬学教育の 中でも長期実務実習への対応が実務家教員に科せられた 最も重要な課題と考えられ，実務実習における医療施設 と大学の連携に関する報告が行われている ${ }^{5-8)}$. しかし 現状では，実務家教員か薬斉師としての知識・技能を維 持向上するための方策など, 解決すべき問題が多く残さ れていると考えられるため，全国の実務家教員が一同に 会し共通の課題・問題について議論する場を設けること は, 臨床薬学教育の充実を図るためにも重要との認識か ら, 平成 18 年 5 月に薬学実務家教員連絡会(仮称)が設 立された。

平成 20 年 3 月までに薬学実務家教員連絡会(仮称)と して4回の会議が開催され，弚こでの議論の中で実務家 教員の実態とあるべき姿を明らかにすることを目的に 「薬学実務家教員の実態に関する調査」(アンケート調査) を実施することになった . 本報告では平成 19 年 10 月に 実施したアンケート調査結果について報告するととも に，実務家教員のあるべき姿について考察した 。
方法

全国 66 の薬系大学(表1)の実務家教員を対象にアン ケート調査を行った，実施方法としては，全国を北海 道，東北，関東甲信越，東海，北陸，近畿，中国四国， 九州の8支部に分け, 取りまとめを担当した京都大学か ら平成 19 年 10 月 5 日に各支部世話人にアンケート用紙 をメールで配信した . 支部世話人は支部所属の各大学連 絡員にメール配信し, 大学連絡員は自大学の実務家教員 にさらにメール配信した . 個々の実務家はアンケートに 対応した個人回答表に結果を記入した後, 大学連絡員に 返送した . 大学連絡員は支部世話人に大学ごとの個人回 答表を送付すると同時に, アンケート対象教員数と回答 教員数を回答した(平成 19 年 10 月 31 日締切). 光の 後, 支部世話人は個人回答表を支部別集計表に集計し, 京都大学に送付した(平成 19年 11月 30 日締切).支部 別集計表を基に全国集計を行った . 図 $\mathbf{1}$ に実施に用いた アンケートを示す .なお，本アンケートの内容およびそ の実施については第 3 回薬学実務家教員連絡会(仮称)(平 成 19 年 9 月 28 日, 前橋市)において決定され, アンケー トへの回答は各実務家教員の自由意志で行われたもので ある.また，結果の公表については，第 4 回薬学実務家 教員連絡会(仮称)(平成 20 年 3 月 26 日, 横浜市)で承認 を得た。

表 1 . アンケート配布大学一覧

\begin{tabular}{|c|c|c|c|c|c|c|c|}
\hline 1) 北海道支部 & & & & & & & \\
\hline 北海道大学 & 北海道医療大学 & 北海道薬科大学 & & & & & \\
\hline 2) 東北支部 & & & & & & & \\
\hline 青森大学 & 奥羽大学 & 東北大学 & 東北薬科大学 & & & & \\
\hline 3)開東支部 & & & & & & & \\
\hline 北里大学 & 共立薬科大学 & 国際医療福祉大学 & 城西大学 & 城西国際大学 & 昭和大学 & 昭和薬科大学 & 高崎健康福祉大学 \\
\hline 千葉大学 & 千葉科学大学 & 帝京大学 & 帝京平成大学 & 東京大学 & 東京薬科大学 & 東京理科大学 & 東邦大学 \\
\hline 新潟薬科大学 & 日本大学 & 日本薬科大学 & 星薬科大学 & 武蔵野大学 & 明治薬科大学 & 横浜薬科大学 & \\
\hline 4) 東海支部 & & & & & & & \\
\hline 愛知学院大学 & 岐阜薬科大学 & 金城大学 & 県立静岡大学 & 名古屋市立大学 & 名城大学 & & \\
\hline 5) 北陸支部 & & & & & & & \\
\hline 金沢大学 & 富山大学 & 北陸大学 & & & & & \\
\hline 6) 近畿支部 & & & & & & & \\
\hline 大阪大学 & 大阪大谷大学 & 大阪薬科大学 & 京都大学 & 京都薬科大学 & 近畿大学 & 神戸学院大学 & 神戸薬科大学 \\
\hline 摤南大学 & 同志社女子大学 & 姫路獨協大学 & 兵庫医療大学 & 武庫川女子大学 & & & \\
\hline 7) 中国四国支咅 & & & & & & & \\
\hline 岡山大学 & 就実大学 & 德島文理大学 & 德島文理大香川 & 広島国際大学 & 福山大学 & & \\
\hline 8) 九州支部 & & & & & & & \\
\hline 九州大学 & 九州保健福祉大学 & 熊本大学 & 崇城大学 & 第一薬科大学 & 長崎大学 & 長崎国際大学 & 福岡大学 \\
\hline
\end{tabular}




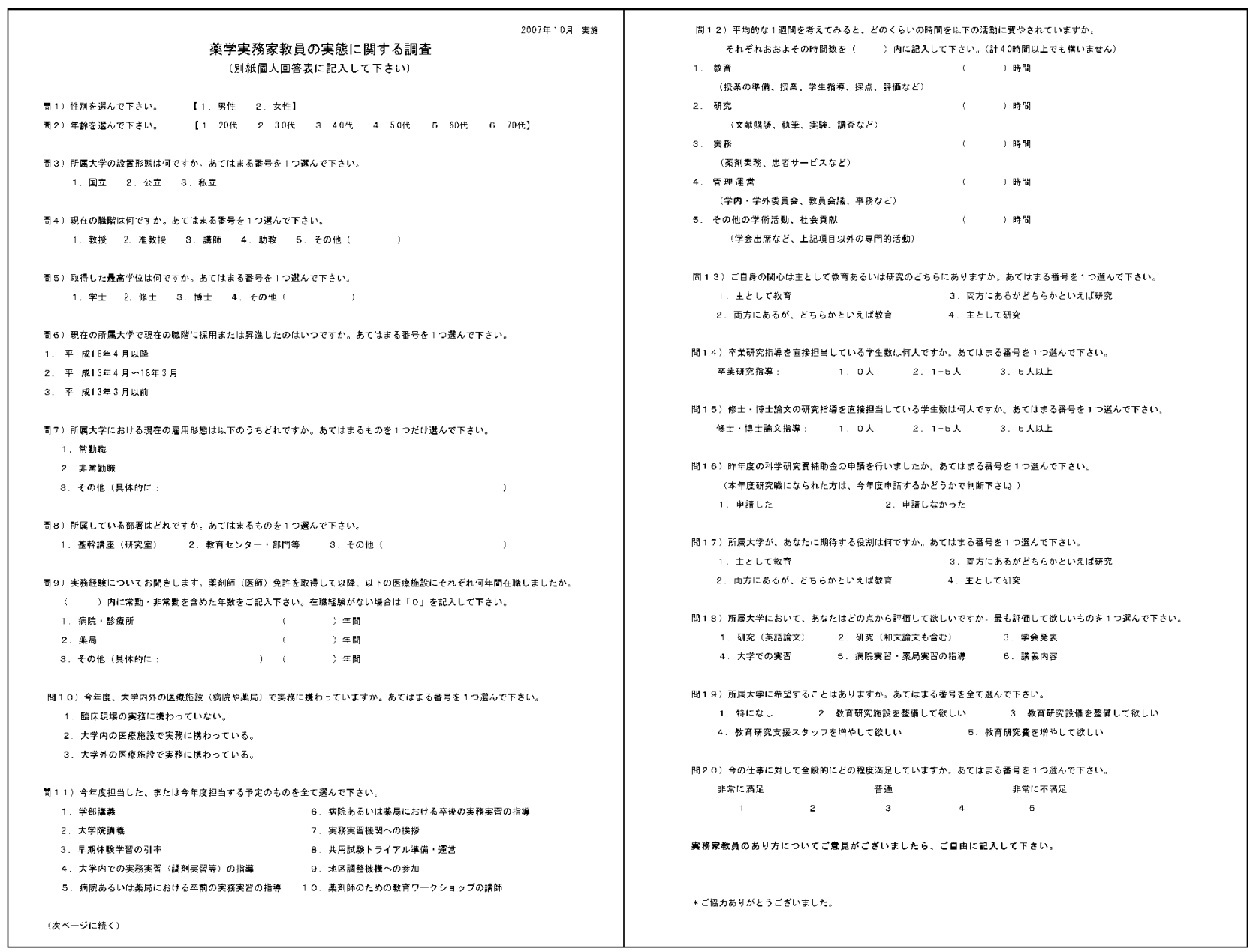

図 1 .「実務家教員の実態に関する調査」アンケート

\section{結＼cjkstart果}

全国薬系大学実務家教員 247 人にアンケート用紙を配 布し，うち209人分を回収した(回収率 84.6\%). 図 2 に は問 1から問 8 までの結果を示す. 男女比は 8:2で, 40 代以下の回答者が半分以上を占めていた . 国公立大 学の教員は $16 \%$ で, 残りは私立大学教員であった . 職 階は, 講師以上が $89 \%$ を占め, 博士の学位取得者は 77 \%を占めていた . 現在の職階についた時期は, 平成 18 年 4 月以降が $56 \%$ を占め, 勤務形態は $97 \%$ が常勤で, 所属部署は基幹講座が $69 \%$, 教育センター・部門所属 が $27 \%$ であった .

図 3 は, 現在までの実務経験年数と今年度(平成 19 年 度)の実務実態を示す . 問 9 は回答者全員の延べ経験年 数を全回答者数 $(N=209)$ て割つた平均值を示し, 病院・ 診療所での実務経験年数 16.9 年に対して, 薬局は 2.0 年 であった．また，回答者の $67 \%$ は平成 19 年度に臨床実 務に携わっていなかった(問 10).

多くの教員が担当している教育関連項目は, 学部講義 (71\%), 早期体験学習の引率 $(67 \%)$, 大学内での実習指 導 $(70 \%)$ ，実習機関への挨拶(68\%)，共用試験準備(73\%) であり，一方，臨床現場で実習指導を担当している教員
は 37\% と少なかった(図 4 , 問 11). 平均的 1週間にお ける活動時間は教育が最も多く(20.6 時間)，次いで，研 究(12.2 時間)，管理運営(9.6 時間)の順であった .一方， 臨床実務に携わる時間は平均 3.5 時間と少なかった(問 12) .

教育あるいは研究に対する自分自身の関心では, 主と して教育とどちらかといえば教育との回答者があわせて 73\% であり(図 5 , 問 13)，どちらかといえば研究(25\%) の約 3倍であった . 卒業研究担当学生や修士/博士論文

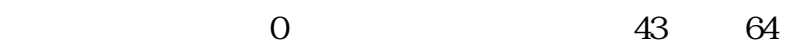
を占めていたが，一方で，5人以上と答えた回答者も光

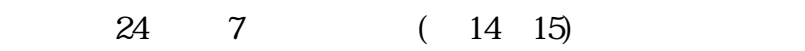
申請率は 55\% であった(問 16) . 大学が回答者に期待す る役割として，主として教育とどちらかといえば教育と の回答者があわせて $92 \%$ を占め, どちらかといえば研 究(6\%)との回答はわずかであった(問 17) . 大学に評価 して欲しい項目は多岐にわたつたが，実習への対応と回 答した例が多く学内外での実習をあわせると $62 \%$ を占 めていた(問 18).

大学に対する希望としては, スタッフの充実と回答し た教員は全体の $79 \%$ であり，施設の充実(38\%)や設備 の充実 $(37 \%)$, 教育研究費の充実 $(47 \%)$ を上回っていた 


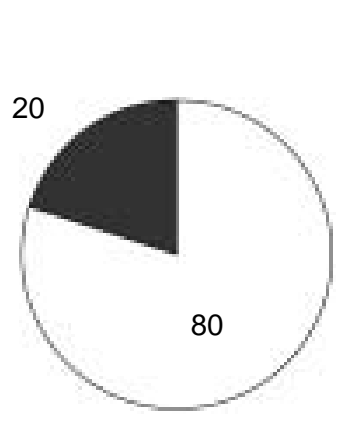

問 1：性別

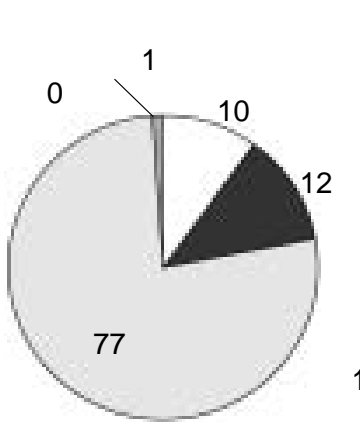

問 5：取得学位

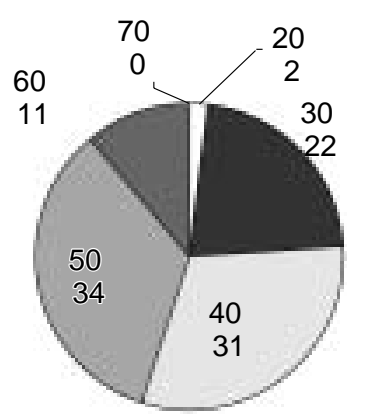

問 2：年齢

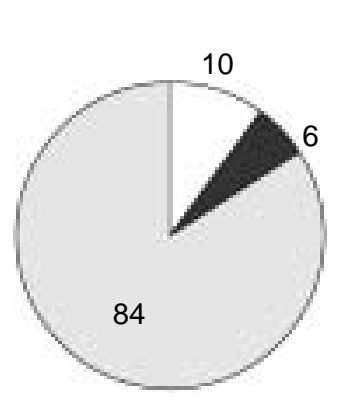

問 3：大学の設置形態

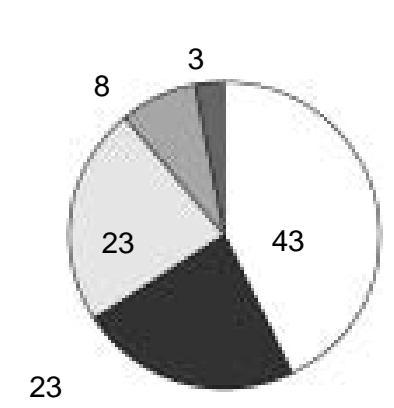

問 4：現在の職階

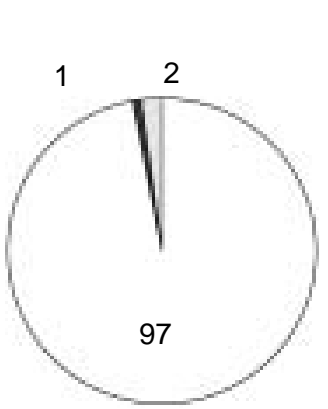

問 7：勤務形態

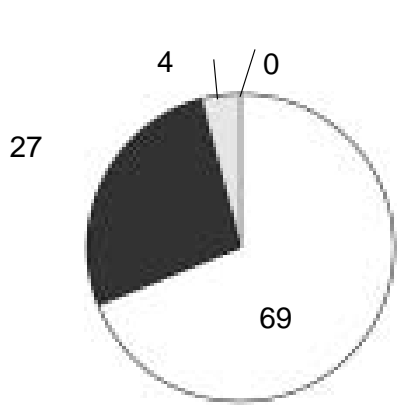

問 8：所属部署

図 2 . アンケート回答者の背景(問 1～8)

(年/人)

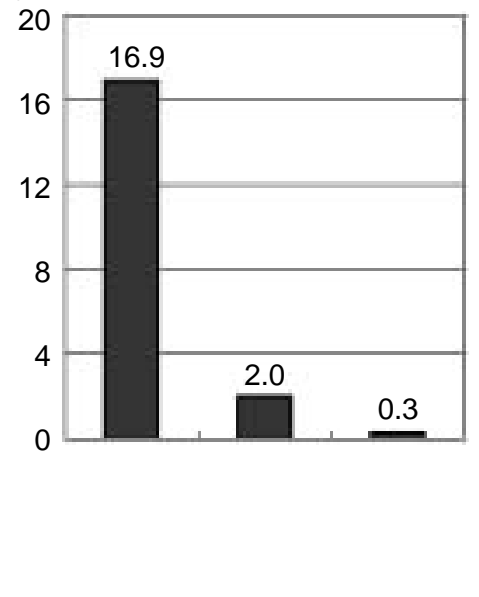

問 9: 実務経験年数

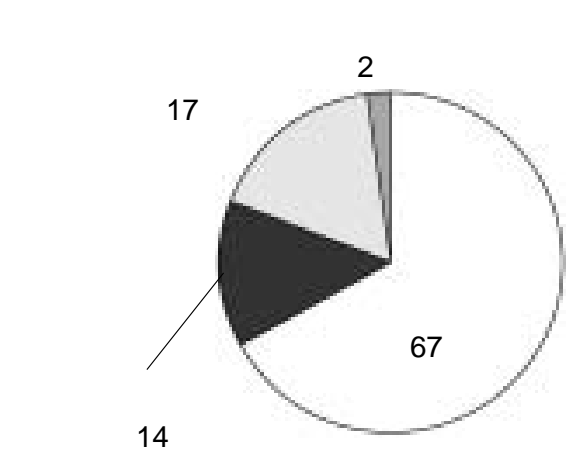

問 10：今年度の実務実態

図 3 . 実務に関する設問(問 9,10)
(図 6, 問 19) . 現在の仕事に対する満足度は5段階で， 非常に満足，まあまあ満足は合わせて $26 \%$ に留まった が，普通をあわせると $70 \%$ であった(問 20) . 実務家教 員のあり方に関する記述式設問では，継続的に臨床実務 に携わることの重要性を指摘する意見が多く，一方で研 究にも力を注ぎ, 大学内で教育・研究者として認知され るとともに, 臨床現場からも評価されることが重要との 指摘等があった(表 2) . また，大学に対する要望とし て，実務家教員に対する認識・理解が不十分である，講 義・実習等に追われ研究の時間がとれない, 実務家教員 の業務内容や評価について今後も検討が必要，という意 見等が挙げられた 。

考察

薬学実務家教員連絡会(仮称)は, 金沢大学薬学部山田 清文教授(当時)の発案で全国 8支部の設立発起人のも と，平成 18 年 5 月に設立された .「すべての薬学部の実 務家教員が一同に会し，実務家としての知識・技能を維 持向上するための方策など，実務家教員に共通する問題 について協議し，臨床薬学教育の充実を図る」ことを設 立の趣旨・目的として，これに賛同した実務家教員を対 象に名簿の登録を行った. 光の後, 第1回連絡会(平成 18 年 9 月，金沢市)，第 2 回連絡会(平成 19 年 3 月，富 山市)において，連絡会の正式名称や他の会議との連携 等について議論を行ったが, 本会の趣旨・目的を考慮し 慎重に決定する必要があるとの意見から，会の名称は暫 定的に薬学実務家教員連絡会(仮称)となっている.こう 
(人)

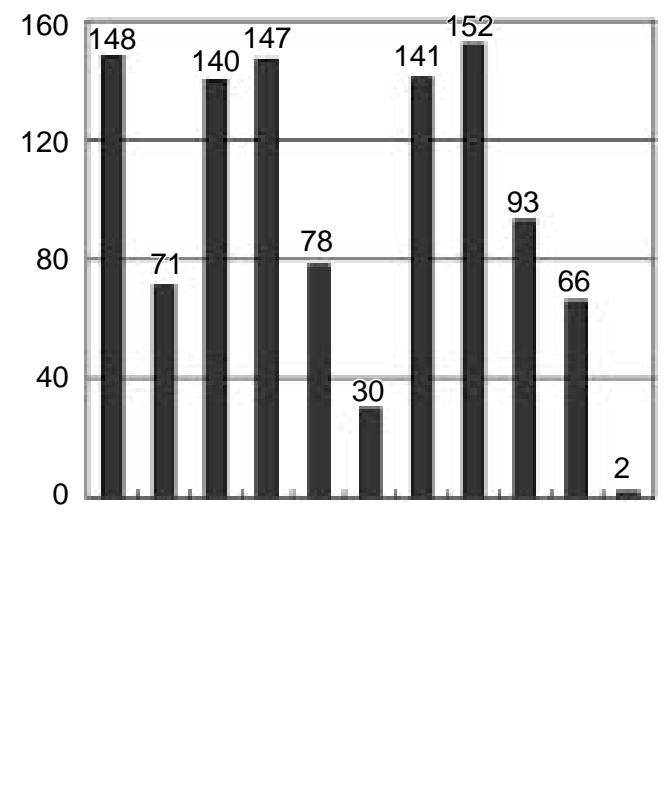

問 11: 今年度担当した教育関連項目 (複数回答可, $N=209$ 人) (時間/人)

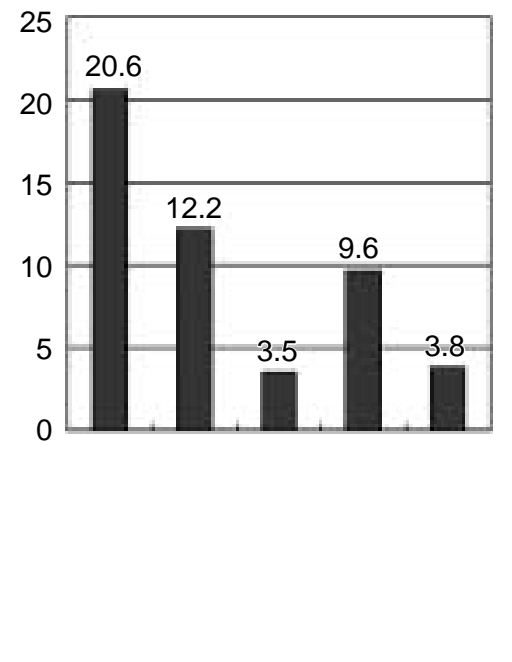

問 12: 平均的な 1 週間における活動状況

図 4. 教員活動に関する設問(問 11，12)

した連絡会議の議論の中で, 個々の実務家教員の背景は さまざまで大学における位置づけや役割も多岐にわたる ことが挙げられた . 乥こで, 実務家教員の実態について 明らかにすることが実務家教員の共通の課題，あるべき 姿を探る上で役立つとの考えから，第 3 回連絡会(平成 19年 9 月，前橋市)の参加者を対象にアンケート調査を 行うこととなった．しかし，第 3 回連絡会では参加者が 63 名と少なかったため, 連絡会のメンバー全体(平成 20 年 3 月 26 日現在の名簿登録者は 242 名)を把握すること は難しいという結論に至り，後日，実務家教員全員を対 象にアンケートを実施することになった . 以上が , 今回 のアンケート調査実施の背景である .
アンケートでは回答者数の規模を優先し, また, 集計 における人的制限があったため, 方法に記載のように各 支部世話人が回収・集計するメールでのアンケート調査 となり, 設問ごとの単純集計を行うのみで, 詳細な解析 を行うことができなかった . しかし，今回のアンケート 調査は, 回収期限の延長と支部世話人の精力的な働きか けの結果, 全国薬系大学 66 に所属する 209 人の実務家 教員から回答を得ることができたことから(回収率 84.6 \%), 実務家教員の実態をかなり反映したデータであ り，かつこうした調査は全国で初めて行われたものであ ることからも，非常に貴重なデータといえる．

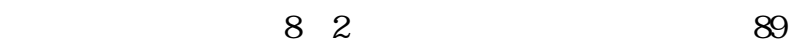
\%を占めていた . また，20代，30 代の教員が $25 \%$ を占 めており，博士取得者は $77 \%$ であったことから，若手 実務家教員に対する臨床業務のさらなる充実と, 学位取 得率の向上が今後の課題として挙げられる. また , 現在 の職階についた時期について, 平成 18 年 4 月以降が半 数以上を占めたことから, 薬学 6 年制教育制度の開始と ともに，医療機関から実務家教員として移籍した教員の 多いことが改めて明らかとなった .一方で, 平成 18 年 以前から現在の職階についている教員も多く，こうした 教員の場合には, 大学内での位置づけや基盤もしつかり しており, 実務家以外の教員と同等の教育・研究へのか かわりを行っているではないかと考えられる．また，所 属部署としては, 基幹講座 $69 \%$ に対して, 教育セン ター・部門所属が $27 \%$ あり，大学内で期待される役割 も所属部署によっておのずと異なり，教育と研究の比重 も異なるように考えられる．

実務に関する調査では, 病院・診療所での経験者が多 く, 実務家教員 1 人あたりの平均年数は 16.9 年と長く, 40 代，50 代の実務家教員があわせて $65 \%$ であることと 対応していると考えられる．一方, 薬局での経験者は少 なく, 実務家教員 1 人あたりの単純平均では 2.0 年と病 院・診療所の場合の $1 / 8$ と短かった . 薬学 6 年制での実 務実習は病院と薬局の双方で11週間ずつ行われること から，薬局薬阂師か実務家教員としてさらに活躍するこ とか望まれる。

本アンケート調査で最も注目に值する結果として, 実 務家教員の $67 \%$ が今年度実務に携わっていないと回答

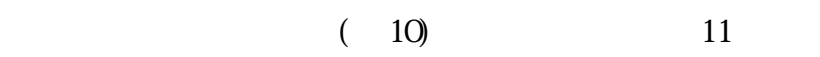
床現場での実習指導を担当している教員が $37 \%$ である ことと対応している.また，平均的な1週間における活 動状況として, 回答者 209 人の単純平均として実務は 3.5時間であることから(問 12)，実務に携わっていると 回答した教員(65人)だけの平均時間としても，1週間あ たり実務に携わる時間は約 11 時間となる(3.5× 209: 65)．医学部教員(医師)の場合には，1週間に 1 日程度は 外来診療に携わっていることを考えれば,実務家教員(薬 剂師)の場合にも最低1週間に1日程度は実務に携わる ことが, 臨床能力の維持・向上の上でも必要ではないか 


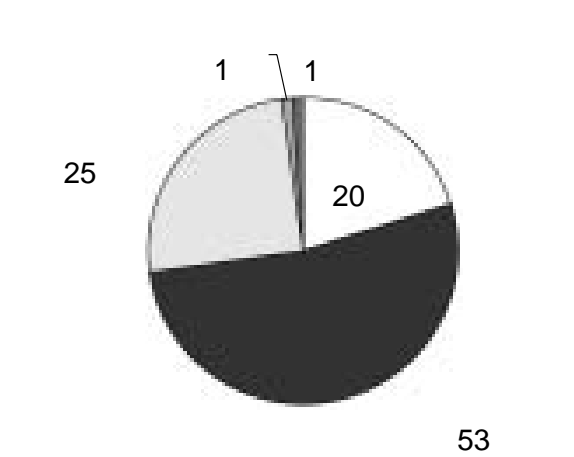

問 13: 自分自身の関心

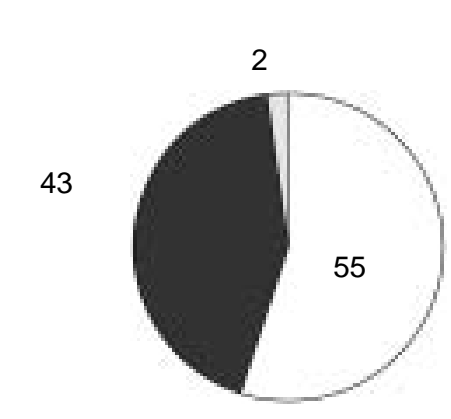

問 16：科学研究費の申請

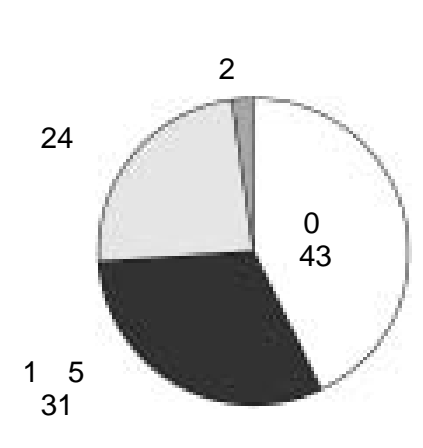

問 14：卒業研究担当学生数

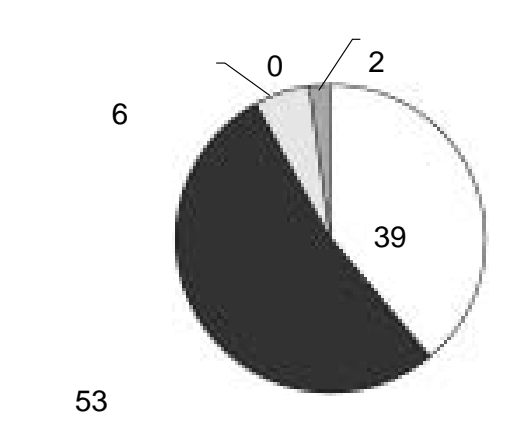

問 17：大学が期待する役割

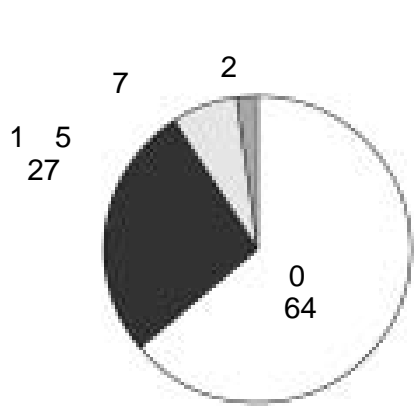

問 15: 修士 /博士論文指導学生数

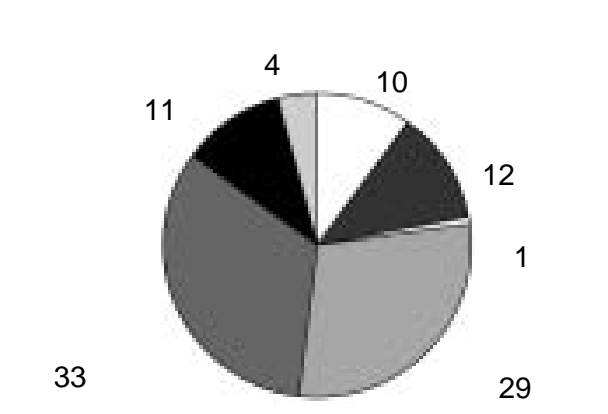

問 18：大学に評価して欲しいこと

図 5 . 教育研究に関する設問(問 13～18)

(人)

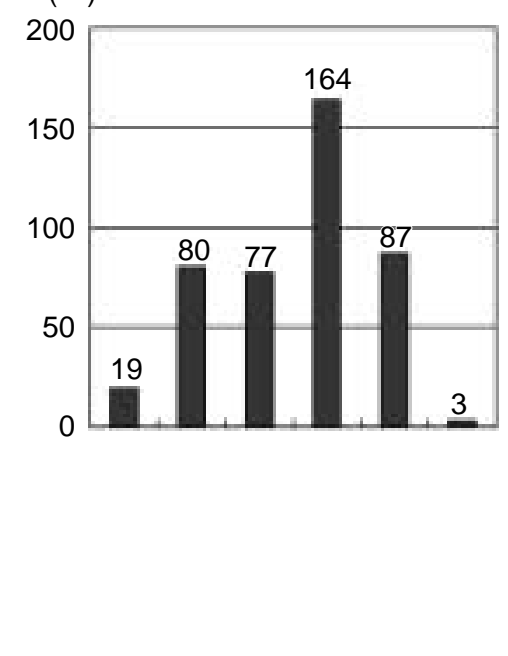

問 19：大学に対する希望 (複数回答可, $\mathrm{N}=209$ 人)

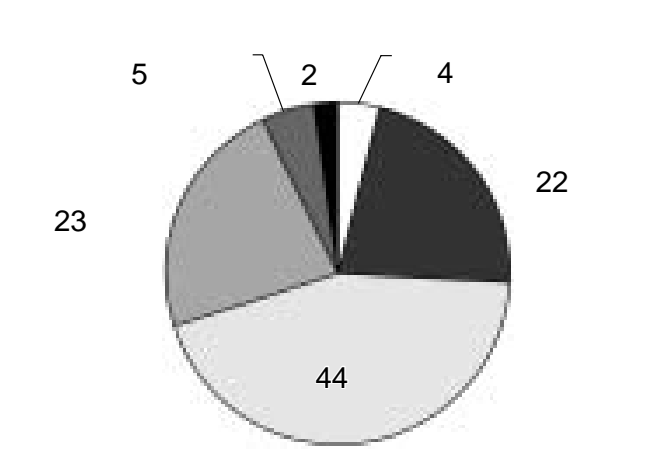

問 20：今の仕事に対する満足度
表 2 . 実務家教員のあり方に関する意見 (記述式, 複数回答可, 同一意見はまとめて記載)

1) 実務家教員のあるべき姿について

継続的に臨床実務に携わる (臨床経験の維持)

現場を離れたら実務家教員でない

実務家教員の年間の病院・薬局研修制度の創立

外部施設に常駐するときの立場は正式なスタッフであるべき

現場と大学の橋渡し的役割を果たす(学内外で信頼され高 い地位を持つ)

大学の中で教育者, 研究者として認知されること, そして 臨床現場からも評価されること

実務家教員として薬学を正しい道に導くこと

薬剤師の業務の質の向上に貢献する立場にある

調剂行為の標準化

研究でも頑張ってほしい

科学研究費の獲得が大事

2) 大学に対する要望

臨床教育に対するスタッフ不足

開局薬棛師からも教員を採用すべき

6 年制に関する課題の処理が多忙すぎる

講義, 実習で身動きがとれない

大学での実務家教員に対する認識・理解が不十分

教員全体が薬剤師教育に助け合うべきである

実務家教員には研究の環境も 時間もない

論文, 研究至上主義の見直し

実務家教員の業務内容や評価について今後も検討が必要 大学には何も期待しない

図 6 . 大学に対する希望と満足度(問 19,20 ) 
と考えられる .

教育・研究活動に関する調査では，どちらかといえば 研究よりも教育に関心がある実務家が多かったが(問 13)，大学が実務家に期待する役割は, より教育に比重 がかかっていた(問 17). また，卒業研究担当学生や修士 /博士論文指導学生数では, 0 人との回答が光れ年れ 43 $\%$ と $64 \%$ を占め, 科学研究費の申請率も $55 \%$ であった (問 14-16). 今後，6年制課程学生の卒業研究や，6年制 卒業後の大学院教育における臨床研究の重要性を踏まえ ると，実務家教員か臨床研究指導にも一層貢献すること か望まれる．

大学に対する要望としては, スタッフの充実が最も多 かったが(問 19)，これは実務家教員に限らず薬学部教員 の多くに共通する要望と考えられる．しかし，表 2 の実 務家教員のあり方に関する記述式意見とあわせて考える と，一部の大学では臨床系の講義や実務実習に限らず， 弚の他共用試験準備や実習施設への対応といった 6 年制 に関する課題がすべて実務家教員に一任されている状況 が伺える.薬学 6 年制教育の趣旨を考えると，実務家教 員は旧課程の薬学部教育の中で不足していた臨床薬学教 育・研究を担う役割があり，また，臨床現場と大学の橋 渡し的存在であるべきであると考えられる．実務家教員 という名称は薬学部に限らず専門職大学院でも規定され ているが, 特に医療等の変化の激しい分野では, 実務家 は現場と行き来しながら教育にあたることが不可欠であ る. 実務家がまったく現場を離れてしまったとしたら， 現場に即した実務教育を続けることはできない．また， 臨床現場での経験は新たな研究展開にも繋がる可能性が ある．実務家教員には「実務経験」に加えて「実務能 力」と「教育上の指導能力」,「研究能力」が必要と考え られる。

以上, 本アンケート調査の結果, 全国の薬学実務家教 員の実態が初めて明らかとなり，多くの実務家教員が現 在実務に携わっておらず, 研究にも十分時間を費やすこ とができていない状況や，一部の大学では 6 年制に関す る課題が実務家教員に一任されている現状が明らかと なった . 個々の実務家教員の臨床薬学教育に対する意識
やモチベーションの向上が重要であることはいうまでも ないが，本調査結果が実務家教員のあり方についての問 題提起となり，臨床薬学教育を充実させるために，薬学 関係者の間で今後十分な議論が展開されることを期待す る.

謝辞＼cjkstart本調査にご協力いただきました薬学実務家教員連絡 会(仮称)の皆樣に深謝致します.

\section{引用文献}

1) 文部科学省高等教育局医学教育課中央教育審議会, 薬学 教育の改善・充実について(答申)，2004年 2 月 18 日.

2) 日本薬学会, 薬学教育モデル・コアカリキュラム, 薬学 教育実務実習・卒業実習カリキュラム，2002年 8 月.

3) 文部科学省薬学教育の改善・充実に関する調査研究協力 者会議実務実習モデル・コアカリキュラムの作成に関 する小委員会, 実務実習モデル・コアカリキュラム， 2003 年 12 月 3 日.

4) 大学設置基準別表第一个備考第 9 号の規定に基づき薬学 関係(臨床に係る実践的な能力を培うことを主たる目的 とするもの)の学部に係る専任教員について定める件(文 部科学省告示第 175 号)，2006 年 12 月 15 日.

5) 永田将司，岩切智美，熊谷有紀，日高宗明，奥村学，有 森和彦, 鈴木彰人, 河内明夫 , 徳永仁, 平井正巳 , 高村 徳人，本屋敏郎，山本隆一，実務実習教育における医療 施設と大学との連携と光の評価 - 医療施設への大学教員 の派遣 - , 日本病院薬剂師会杂隹誌, 43, 1095-1098 (2007).

6) 北原隆志, 樋口則英, 一川暢宏, 神山朝光, 深堀京子, 岩松洋之, 相川康博，佐々木均，薬学 6年制における実 務実習教育の内容と実施体制に関する大学側・受入施設 側の実態調査，医療薬学，33，619-626 (2007).

7) 岡崎宏美, 相良英憲, 名和秀起, 北村佳久, 千堂年昭, 五味田裕，薬学教育 6 年制における長期実務実習に向け た取り組み(第 3 報) - 病棟業務実習へのポートフォリオ 評価導入 - , 医療薬学, 33, 591-600 (2007).

8) 永田将司, 日高宗明, 大野梨絵, 岩切智美, 奥村学, 有 森和彦，鈴木彰人，河内明夫，德永仁，平井正巳，高村 徳人, 本屋敏郎, 山本隆一, 薬学部教員主導によるグルー プ病院実習の試みと評価，医療薬学，34，256-262 (2008). 